\title{
Cam Atık Çamuru ile Güçlendirilmiş Kilin Mukavemet, Oturma ve Şişme Davranışlarının İncelenmesi: Çevre Dostu Bir Zemin İyileștirme Yaklaşımı
}

\section{Investigation of Strength, Settlement and Swelling Behavior of Glass Waste Sludge Treated Clay: An Eco-Friendly Soil Improvement Approach}

\author{
Barış Mahmutluoğlu1 ${ }^{\text {iD }}$, Baki Bağrıaçık*2 iD \\ ${ }^{I}$ Mersin Üniversitesi, Teknik Bilimler Meslek Yüksekokulu, Inşsaat Bölümü, 33110, Mersin, TÜRKIYYE \\ ${ }^{2}$ Çukurova Üniversitesi, Mühendislik Fakültesi, İnşaat Mühendisliği Bölümü, Balcall, 01330, Adana, TÜRKIYE
}

Başvuru/Received: 19/07/2020

Kabul / Accepted: 19/03/2021

Çevrimiçi Basım / Published Online: 27/05/2021

Son Versiyon/Final Version: 18/06/2021

\section{$\ddot{O} \mathbf{z}$}

$\mathrm{Bu}$ çalışmada, cam endüstrisinin bir ön-atığı olan cam atık çamurunun (CAÇ), killi bir zeminin (CI) mukavemet ve konsolidasyon parametrelerine etkileri incelenmiştir. Son yıllarda, sürdürülebilirlik ve çevre koruma konularında gittikçe gelişen hassasiyet, bu tür atıkların zemin iyileştirme uygulamalarında kullanılmalarını gündeme getirmiştir. CAÇ, cam üretebilmek için gerekli olan mineralojik kısım, ilgili madenden ayrıştırıldıktan sonra ortaya çıkmakta ve sürekli doğada birikmektedir. Bu atığın kullanımı ile gerçekleştirilmiş zemin iyileştirme çalışmaları, ilgili literatürde henüz bulunmamaktadır. Çalışmada, kil-cam atığı karışımlarının en ideal su muhtevası, karışım oranları, mukavemet, oturma ve şişme değişimleri gibi parametreleri irdelenmiştir. Mikro-yapı analizleri gerçekleştirilerek, söz konusu zeminin iç yapısı ve iç-yapı değişimleri gözlemlenmiş ve sonuçta killerin cam atığı ile güçlendirilebileceği, çevre-dostu bir yaklaşımla vurgulanmıştır.

\section{Anahtar Kelimeler}

"Zemin Iyileştirme, Cam Atık Çamuru, Serbest Basınç Mukavemeti, Konsolidasyon, Sürdürülebilirlik, Atık Yönetimi"

\begin{abstract}
In this study, the effects of glass waste sludge, which is a pre-waste product of glass industry, on the strength and consolidation parameters of a clayey soil were investigated. In recent years, the sensitivity that have increasingly grown in aspects of sustainability and environmental protection brought the utilization of these waste products in soil improvement applications to agenda. Glass waste sludge arises in the sequel of extricating the necessary mineralogical part to produce glass from the mined material and is being accumulated in nature consistently. Soil improvement studies regarding the utilization of this waste are not currently present in the relevant literature. In the study, parameters such as the most ideal water content, mixture ratios, strength, settlement, and swelling alterations of clay-glass waste mixtures were examined. By means of conducting micro-structural analyses, internal structure, and internal structural changes of the soil in question were observed and it was emphasized eventually that clays can be improved with glass waste in an environmentally friendly approach.
\end{abstract}

Key Words

"Soil Improvement, Glass Waste Sludge, Unconfined Compressive Strength, Consolidation, Sustainability, Waste Management" 


\section{Giriş}

Atıkların zemin iyileştirme çalışmalarında kullanılması, uzun yıllardır araştırmacıların temel inceleme alanlarından biri olmuştur. Bu atıklar ya tek olarak ya da başka atık malzemelerle beraber kullanılarak birçok deneysel ve teorik çalışma gerçekleştirilmiştir. Atık malzemelerin çevreye atılması ile doğa için bir tehlike oluşması, atıkların depolanması, bertaraf edilmesi, atıklar için ödenmesi zorunlu olan ağır vergiler ile malzemelerin mühendislik özelliklerinin iyileştirilmesi için kullanılması gerekli olan pahalı kimyasal maddelerin kısmen ya da tamamen uygun atık malzemelerle değiştirilmesi gibi unsurların bir arada değerlendirilerek optimize edilmesi, çok yönlü fayda sağlayabilecek bir yaklaşım olarak ortaya çıkmaktadır.

İlgili literatür incelenecek olursa, atık malzemeler kullanılarak zeminlerin mühendislik parametrelerini geliştirme alanında yapılmış olan çalışmalara rastlanılabilir. Örneğin, Abbaspour vd. (2019) tarafindan gerçekleştirilmiş olan deneysel bir çalışmada, killi ve kumlu zeminler, atık lastik tekstil liflerinin bu zeminlere $\% 0.5, \% 1, \% 2, \% 3$ ve $\% 4$ oranlarında karıştırılması ile güçlendirilmeye çalışılmıştır. Çalışma sonunda, \%1 oranında atık lastik tekstil lifi eklenmesinin killi zeminlerin basınç mukavemetlerinde önemli oranda düşüşler, kumlu zeminlerde ise yine aynı oranda atık malzeme için basınç mukavemetlerinde artışlar gözlemlenmiştir. Güllü (2014) tarafından yürütülmüş olan başka bir çalışmada, ince daneli zeminlere $\% 0, \% 5, \% 10, \% 15, \% 20$ ve $\% 25$ oranlarında taban külü adı verilen bir atık malzeme katılmış ve bu atığın söz konusu zeminlerin serbest basınç mukavemeti, şekil değiştirme oranı, elastiktik özellikleri ve enerji emme kapasitelerindeki zaman içinde oluşan etkiler incelenmiştir. Sonuç olarak, \%25 atık oranına kadar, bahsi geçen parametrelerde kayda değer bir değişime rastlanılmamış olup, en ideal etkinin \%30 atık eklenmesi durumunda elde edildiği vurgulanmıştır. Liu vd. (2019) tarafından, çimento, pirinç kabuğu külü ve kalsiyum karbür artığı malzemeleri zemin iyileştirme amacıyla deneysel olarak incelenmiştir. Sonuç olarak, pirinç kabuğu külü ve kalsiyum karbür artığ1, söz konusu zemin örneklerinin kohezyon ve içsel sürtünme açısı değerlerini yüksek oranda arttırmıştır. Killi bir zeminin basınç mukavemetinin, 7,14 ve 28 günlük kür süreleri sonrasında, $\% 3$ ve $\% 6$ çimento ile $\% 0, \% 2.5, \% 5, \% 7.5$ ve $\% 10$ oranlarında lastik lifleri eklenmesi suretiyle ne oranlarda değiştiği Yadav vd. (2019) tarafından gözlemlenmiştir. Çalışma sonucunda, \%7.5 değerinde lastik lifleri eklenmesinin en ideal oran olduğu tespit edilmiştir. Long vd. (2019) tarafından, farklı oranlarda kömür gang malzemesi çimento-zemin karışımlarına eklenmiş; 28 günlük bir zaman periyodu sonrasında karışımların basınç mukavemetlerinde \%81.8 oranında iyileşme meydana geldiği tespit edilmiştir. Alüminyumlu kimyasal bir bileşiğin hidratlaştırılmış çift sülfat tuzlarını içeren bir tür atık su arıtma çamurunun, \%8 oranında şap çamuru ile güçlendirilerek zemin stabilizasyonunda değerlendirilebileceği, Shah vd. (2020) tarafından belirlenmiştir. Taki vd. (2020) tarafından, kireçle stabilize edilmiş atık çamuru kullanılarak zeminlerin mühendislik parametrelerinin iyileştirilme potansiyellerinin mevcudiyeti sorgulanmıştır. Bu amaç doğrultusunda, söz konusu atık çamuruna \%0, \%2, \%4, \%6 ve $\% 8$ oranlarında $\mathrm{CaO}$ eklenmiş ve deney numuneleri 7, 14 ve 28 günlük kür sürelerine tabi tutulmuştur. Deneysel çalışma neticesinde, numunelerin kesme mukavemetlerinde artışlar ve şişme potansiyelleri ile plastiklik özelliklerinde azalmalar tespit edilmiştir. Atık su çamuru külünün, zeminlerin kesme mukavemeti parametrelerine etkileri Ayininuola\&Ayodeji (2016) tarafından deneysel olarak araştırılmıştır. Çalışmada, \%7 oranında eklenen malzemenin, çimentolaşma etkisi yaratmak suretiyle parçacıkları birbirlerine bağladı̆̆ı ve bu süreç sonunda kesme mukavemetlerini arttırdığ atık su arıtma çamuru kullanılarak zeminlerin mukavemet değerleri başarılı bir şekilde arttırılmıştır. İlave olarak, de Figueiredo Lopes Lucena vd. (2014) tarafından yürütülen bir çalışmada, zemin numunelerinin CBR, serbest basınç mukavemeti, dolaylı çekme dayanımı ve elastiklik modülü değerleri, kireç ile stabilize edilmiş atık su arıtma çamuru kullanılarak iyileştirilmiştir. Konu ile ilgili literatür incelenecek olursa, benzer atıklarla gerçekleştirilmiş olan çalışmalara rastlanılabilir. Örneğin, çimento (Tremblay vd., 2002; Gu\&Chen, 2020), çimento firın tozu (Badrawi\&El-kady, 2019), kireç (Bell, 1996; MohdYunus vd., 2016; Correa-Silvia vd., 2018), uçucu kül (Cokca vd., 2009; Biradar vd., 2014; Arulrajah vd., 2018), fırın dışıkları (Kumar\&Sivapullaiah, 2012), pirinç kabuğu (Kumar\&Gupta, 2016), geri dönüştürülmüş beton agregaları (Kianimehr vd., 2019; Yokohama\&Sato, 2019), sığır kazeini (Chang vd., 2018), bioyakı1t silisi (Jin vd., 2018), jeopolimer tozu (Bilondi vd., 2018), cam lifi (Ateş, 2016), mermer tozu ve atığ1 (Gupta\&Sharma, 2014; Ural vd., 2014; James\&Pandian, 2016), kenaf lifi (Esmaeilpour vd., 2019), kiremit tozu (Keerthi vd., 2013), palmiye yağ1 yakıt külü (Pourakbar vd., 2015), atık lastik parçacıkları (Abbaspour vd., 2019; Akbarimehr vd., 2019; Naseem vd., 2019), atık taş tozu (Pastor vd., 2019; Zainuddin vd., 2019), inşaat yıkıntı atığı ve çimento (Bağrıçık\&Mahmutluoğlu, 2020), cam üretim atığı (Mahmutluoğlu\&Bağrıç̧ı, 2021) ve benzeri birçok atık malzeme, zeminlerin iyileştirilmesi amacıyla değerlendirilmiştir.

Literatürde, bahis konusu atıkların tek başlarına olduğu kadar, beraber kullanılmalarıyla ilgili de çalışmalar yer almaktadır. Örnek olarak, Fauzi vd. (2016) tarafından, plastik yüksek yoğunluklu polietilen atıklar ile kırılmış cam parçaları killi zeminlere eklenmiş ve kil numunelerinin CBR değerlerinin, her iki atık türünün karışımlardaki oranlarının arttırılması ile orantılı olarak arttığı saptanmıştır. Lin vd. (2007) tarafından yürütülmüş olan başka bir çalışmada, atık su arıtma çamuru külü ve uçucu kül kullanılarak, yumuşak killi zeminlerin yer aldığı bir yol temel altı incelemesi gerçekleştirilmiştir. Bu çalışmada, atık su arıtma çamuru külünün, uçucu külün yerine kullanılabilecek kapasitede olduğu belirlenmiştir. Hasan vd. (2016) tarafından, şeker kamışı küspesi külü ve sönmüş kireç, bir karayolu temel altı zemininin stabilizasyon çalışmasında birlikte kullanılarak, söz konusu zeminlerin mühendislik parametrelerinde iyileşmeler meydana geldiği gözlemlenmiştir. Uçucu kül ve mısır külü Brooks (2019) tarafından, çimento ile pirinç kabuğu ise Basha vd. (2005) ile Ramakrishna\&Pradeepkumar (2006) tarafından zemin iyileştirme çalışmalarında kullanılmış ve zeminlerin serbest başıç mukavemeti, CBR, plastiklik özellikleri ile bu yöntemlerin uygulama masraflarının olumlu yönde değiştiği saptanmıştır. Sharma vd. (2008) ile Ramakrishna\&Pradeepkumar (2006), yürütmüş oldukları çalışmalarda, kireç, kalsiyum klorür ve pirinç kabuğu külü ile killi zeminleri stabilize etmeye çalışmış ve bu katkı malzemelerinin kilin iyileştirme çalışmalarında değerlendirilebileceğini vurgulamışlarıdır. 
Yukarda bahsedilmiş olan çalışmalar, endüstriyel atık malzemelerinin doğaya birikimi sonucunda oluşacak zararlı etkileri indirgemek, söz konusu atıkların bertaraf edilmesi, depolanması, atıklar için ödenen ağır depolama ve/veya geri dönüştürme vergi ve ücretlerinin azaltılması gibi önemli unsurları amaçlamaktadır. Gerçekleştirilmiş olan bu çalışmada, daha önce bu amaçlarla değerlendirilmemiş olan bir atık malzeme kullanılmıştır. Söz konusu atık, cam endüstrisinin bir ön ürünüdür. Cam üretmek için gerekli olan madenden, cam üretilecek mineralojik kısım ayrıştıııldıktan sonra geriye cam atık çamuru adıverilen bir atık malzeme kalmaktadır. Bu atık, her yıl milyonlarca ton olarak doğaya atılmakta ve ciddi bir çevre kirliliğine yol açmaktadır. $\mathrm{Bu}$ atık malzeme, zemin iyileştirme çalışmalarında değerlendirilerek hem yukarda sıralanan tüm hedeflere hizmet etmekte hem de pahalı güçlendirme malzemelerinin kısmen ya da tamamen yerine geçebilecek potansiyele sahip olması sebebiyle ilgili literatüre önemli bir katkı sağlamaktadır.

\section{Materyal ve Yöntem}

\subsection{Materyal}

Çalışmada kullanılan kil zemin (CI) numuneleri Adana Ill' inden temin edilmiştir. Cam atık çamuru (CAÇ) ise, Mersin-Adana Otoyolu üzerinde yer alan bir cam fabrikasından alınmıştır. CI ve CAÇ' nin alınmış olduğu bölgeler Şekil 1' de gösterilmiştir. Her iki malzeme üzerinde gerçekleştirilmiş olan elek analizi deney sonuçlarına ait dane dağılımı eğrileri, aşağıda Şekil 2' de sunulmuştur. Malzemelerin endeks özelliklerini belirleyebilmek adına, Çukurova Üniversitesi zemin mekaniği laboratuvarında bir dizi deney gerçekleştirilmiştir. CI numunesinin dane birim hacim ağırlık, maksimum kuru birim hacim ağılık ve optimum su muhtevası sırasıyla $27 \mathrm{kN} / \mathrm{m}^{3}, 17.40$ $\mathrm{kN} / \mathrm{m}^{3}$ ve \%18.10 olarak, likit limit, plastik limit ve plastisite indisi değerleri ise, yaklaşık olarak sırasıyla \%42, \%24 and \%18 olarak tespit edilmiştir (TS 1900-1). Kullanılan zemin, TS 1500' e göre, "orta plastisiteli kil" olarak sınıflandırılmıştır. Kil zemin için yapılan analizlerde, zeminin kuvars, kalsit ve kil grubu mineraller (kaolinit, simektit ve vermikülit) içerdiği görülmüştür. CAÇ' nin dane birim hacim ağırlığı ise $27.6 \mathrm{kN} / \mathrm{m}^{3}$ olarak bulunmuştur (Mahmutluoğlu\&Bağrıaçık, 2021).

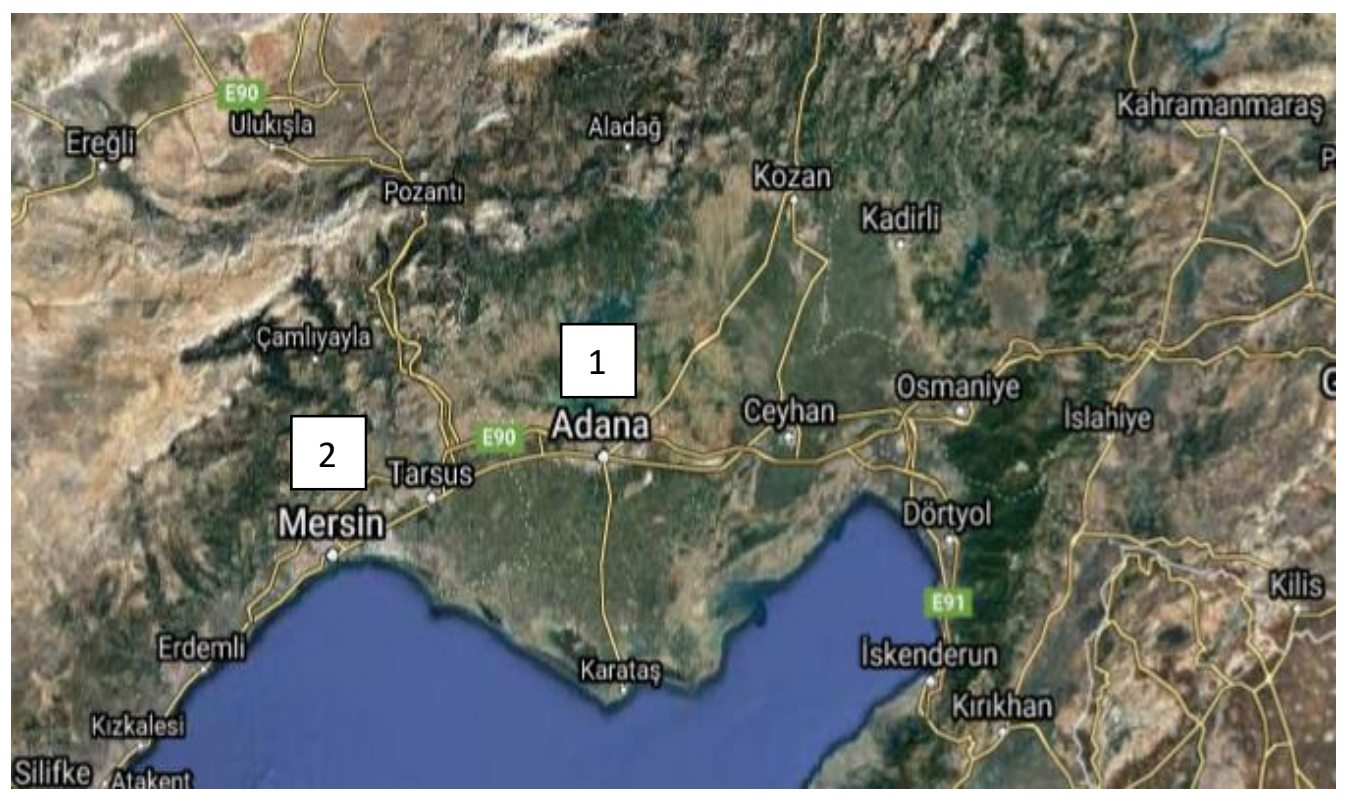

Şekil 1. Numunelerin Alınmış Olduğu Lokasyonlar (1-CI, 2- CAÇ) 


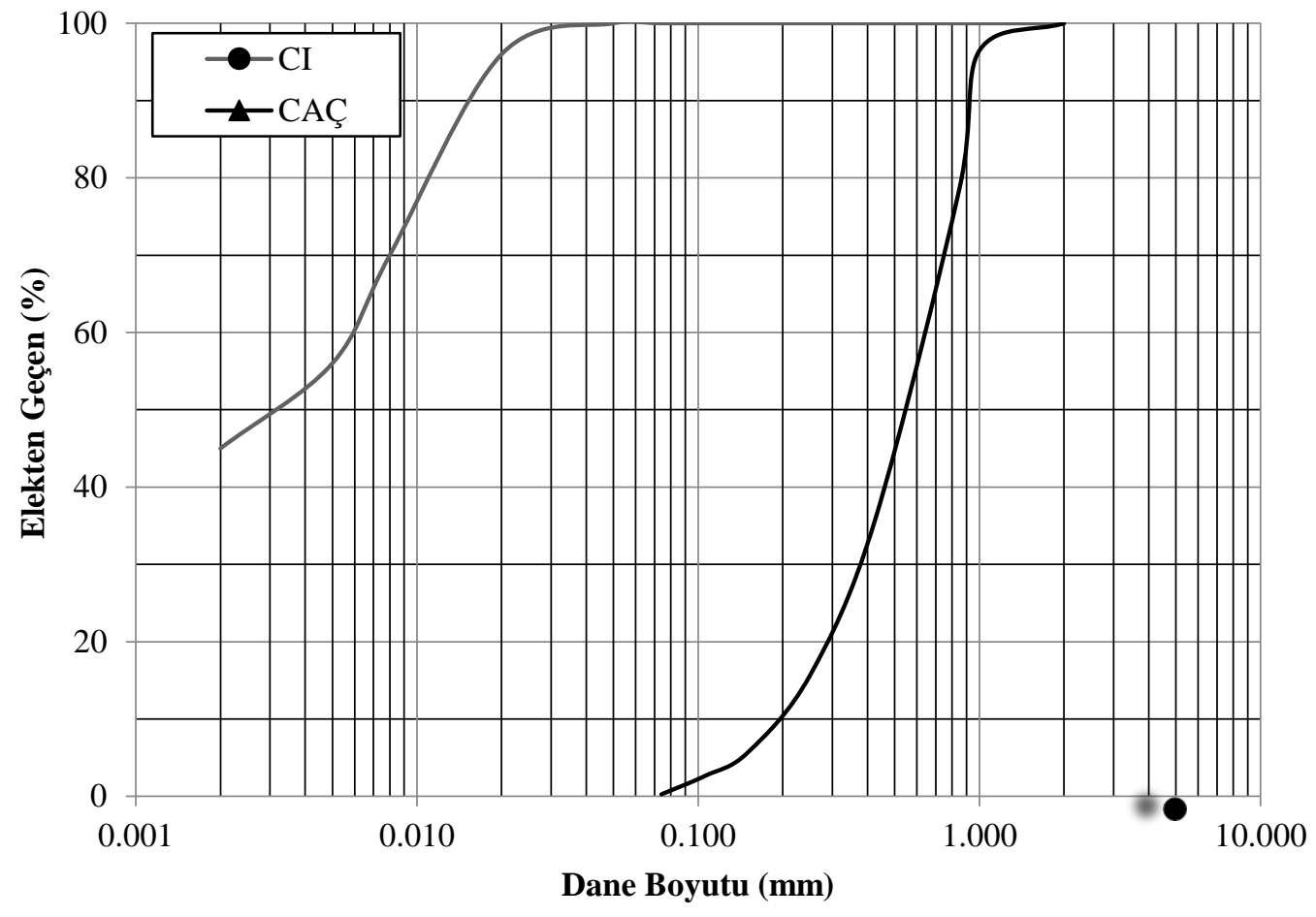

Şekil 2. CI ve CAÇ için Dane Çapı Dağılım Eğrileri

CI ve CAÇ için kimyasal içerikler, XRF (Minipal 4) analizleri gerçekleştirilmek suretiyle belirlenmiştir. Elde edilen kimyasal analiz sonuçları, aşağıda Tablo 1 olarak verilmiştir.

Tablo 1. Kil (CI) ve cam atık çamurunun (CAÇ) kimyasal içerikleri

\begin{tabular}{|c|c|c|c|c|c|c|c|c|c|c|c|c|}
\hline 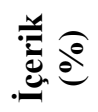 & $\sum_{i=0}^{0}$ & 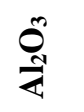 & $\stackrel{0}{0}$ & $\overbrace{n}^{n}$ & $\underset{n}{0}$ & ర్ల & $\stackrel{0}{\xi}$ & ర్ల & $\begin{array}{l}\text { O } \\
\text { Z }\end{array}$ & $\stackrel{0}{0}$ & రิ & $\Xi$ \\
\hline CI & 6.1 & 18.4 & 50.6 & 0.65 & 3.10 & 3.20 & 3.10 & 8.70 & 2.50 & 1.65 & - & 3.15 \\
\hline CAÇ & 6.49 & 8.24 & 18.65 & 8.73 & 8.31 & 22.89 & 9.65 & 7.56 & 5.98 & 3.50 & - & $\begin{array}{l}-10 \\
-\end{array}$ \\
\hline
\end{tabular}

\subsection{Yöntem}

\subsubsection{Mukavemet deneyleri}

Kullanılan cam atığının, kil zeminin mukavemet parametrelerinde gerçekleştirdiği değişimleri belirleyebilmek amacıyla serbest basınç deneyleri yapılmıştır (Şekil 3a). Bir karıştırıcı (Şekil 3b) yardımıyla, \%5, \%10, \%15, \%20, \%25 ve \%30 oranlarında karışımlar yapılarak oluşturulan numunelerde kompaksiyon deneyleri gerçekleştirilmiş ve optimum su miktarları belirlenmiştir. Her karışım oranı için optimum su muhtevasında hazırlanan zemin numunesi, $50 \mathrm{~mm}$ çapında, boyu çapının iki katı, doygun ve kılcal çatlak içermeyecek şekilde oluşturulmuştur (TS1900-2). Zemin numunesi, iki parçalı kalıp yağlanarak çelik tüpe yerleştirilmiştir. Kalıbın iki ağzından taşan zemin numunesi, kıl testere ile kesilip atılmıştır. Oluşturulan deney numuneleri serbest basınç deneyine tabi tutularak dayanımlar belirlenmiştir. Deneylerde, zemin numunesi, presin alt platformuna merkezlenerek oturtulduktan sonra üst başlık numune üst yüzeyine rahatça ve tam değecek şekilde indirilmiş ve bu işlemler ilgili standartta belirtildiği şekilde gerçekleştirilmiştir (TS1900-2). Boy değişimini ölçen komparatör saati, alt ve üst başlıklar arasına yerleştirilerek sıfırlanmıştır. Yüklemeler, numunede dakikada $\% 0.5-\% 2$ arası birim boy kısalması oluşturacak şekilde, standartta belirtildiği gibi yapılmıştır (TS1900-2). Sonuçta, taşıma güçleri belirlenirken, düşey yük-deplasman eğrilerinin pik yaptığı değerler alınmış ve bu pik değerlerin yarısı alınarak kohezyon değerleri belirlenmiştir.

\subsubsection{Konsolidasyon deneyleri}

Deneysel çalışmada, kimyasal sıvıların her bir konsantrasyonu için üçer adet deney numunesi üzerinde konsolidasyon deneyleri yapılmıştır (Şekil 3c). Konsolidasyon deneyleri, TS 1900-2' de belirtildiği şekilde yürütülmüştür. Konsolidasyon deneyi yapılacak olan numuneler, $100 \mathrm{kPa}$ ön-konsolidasyon basıncı altında ön-konsolide edilen zeminden alınmış ve deneylerde iç çapı $50 \mathrm{~mm}$, yüksekliği $20 \mathrm{~mm}$ olan ringler kullanılmıştır. Konsolidasyon hücresi içerisine doldurulan sıvı, ön-konsolide edilen zemindeki karışım sıvısı ile aynı olacak şekilde hazırlanmıştır. Hücre içerisindeki sıvının buharlaşmasını önlemek için hücrenin üst yüzeyi lastik bir kılıf ile kapatılmıştır. Hücre sıvısı içerisinde 1 gün süreyle bekletilerek doygun hale getirilen numuneler, $400 \mathrm{kPa}$ gerilme kademesine kadar yüklenmiştir. Deneyler tamamlandıktan sonra, yük-boşluk oranı grafikleri çizilerek ilgili yorumlar yapılmııstır. Ayrıca, tüm numuneler için şişme basınçları da hesaplanmıştır. 


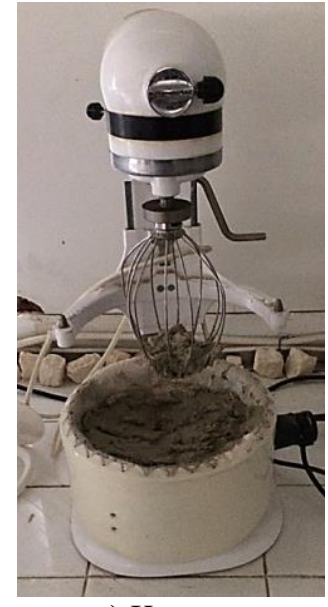

a) Karıştırıcı

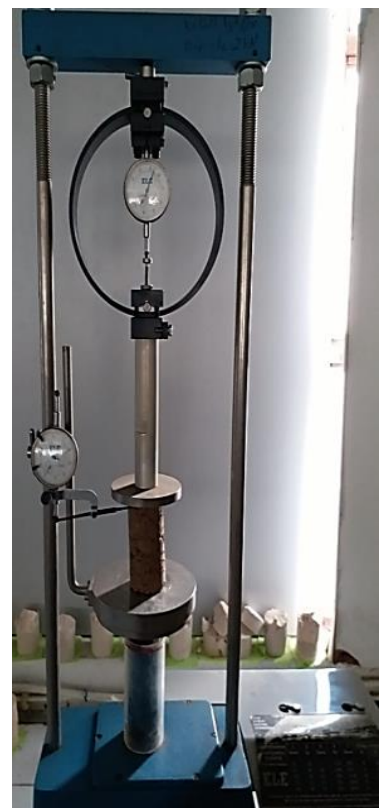

b) Serbest basınç deneyi düzeneği Şekil 3. Deney Düzenekleri

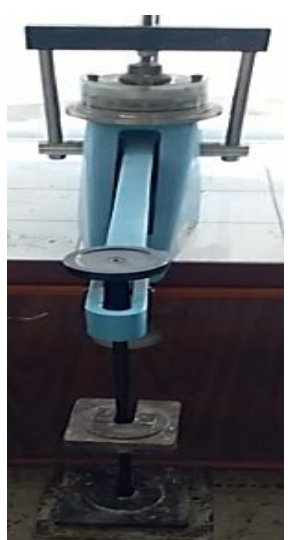

c) Konsolidasyon deney düzeneği

\section{Bulgular ve Tartışma}

\subsection{Optimum Su İçeriklerinin Belirlenmesi}

$\% 5, \% 10, \% 15, \% 20, \% 25$ ve \%30 oranlarında hazırlanmış olan karışımlar için optimum su miktarlarını belirlemek için kompaksiyon deneyleri yapılmış ve sonuçları Tablo 2' de verilmiştir.

Tablo 2. Farklı Karışım Oranları için Kompaksiyon Sonuçları

\begin{tabular}{ccc}
\hline $\begin{array}{c}\text { Karışım Oranı } \\
(\boldsymbol{\%})\end{array}$ & $\begin{array}{c}\text { Optimum Su } \\
\text { Içeriği }\end{array}$ & $\begin{array}{c}\text { Maksimum Kuru Birim Hacim Ăğırlık } \\
\left(\mathbf{k N} / \mathbf{m}^{\mathbf{3}}\right)\end{array}$ \\
\hline 0 & 18.10 & 17.40 \\
5 & 19.56 & 17.46 \\
10 & 19.89 & 17.75 \\
15 & 21.10 & 18.25 \\
20 & 21.35 & 18.39 \\
25 & 21.55 & 18.93 \\
30 & 21.69 & 18.46 \\
\hline
\end{tabular}

Sonuçlara göre, CI içindeki CAÇ oranı arttıkça, karışımın birim hacim ağırlığının arttığı gözlemlenmiştir. Ayrıca, CAÇ oranının artmasıyla daha iyi sıkışmanın oluşması için eklenmesi gereken su miktarının da arttığı belirlenmiştir. Yine, \%25 CAÇ eklenmesi durumunda, Tablo 2' den de gözlemlenebileceği gibi, en yüksek maksimum kuru birim hacim ağırlık değerine ulaşılmış ve $\% 25$ den daha yüksek oranlarda CAÇ eklenmesinin maksimum kuru birim hacim ağırlığı düşürdüğü belirlenmiştir.

\subsection{Karıșımların Mukavemet Parametrelerinin Belirlenmesi}

$\% 5, \% 10, \% 15, \% 20, \% 25$ ve $\% 30$ oranlarında hazırlanan karışımlar için hazırlanan numuneler üzerinde serbest basınç deneyleri yapılmış ve elde edilen sonuçlar Şekil 4' te verilmiştir. Sonuçlara bakıldığında, artan CAÇ oranına bağlı olarak serbest basınç mukavemeti değerlerinin de kayda değer oranlarda arttığı gözlemlenmiştir. \%25 CAÇ oranından sonra serbest basınç mukavemetlerinde kayda değer artışlar gözlemlenmediği için, \%25 oranından fazla katkının eklenmesinin serbest basınç mukavemetinde bir iyileşmeye neden olmayacağ belirlenmiştir. 


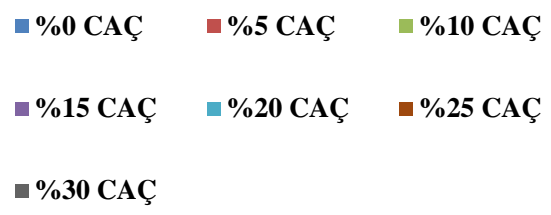

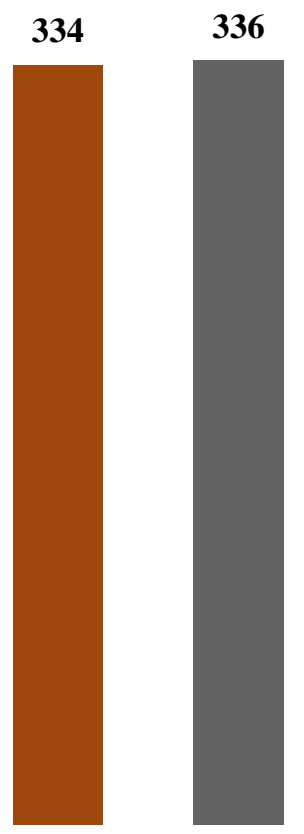

Unconfined Compressive Strength (kPa)

Şekil 4. Farklı CAÇ Oranları için Serbest Basınç Mukavemetleri

\subsection{Karışımların Oturma Parametrelerinin Belirlenmesi}

Cam atık çamurunun, kilin konsolidasyon ve şişme davranışına olan etkilerinin araştırılması amacıyla laboratuvarda bir seri konsolidasyon deneyi gerçekleştirilmiştir. İlave olarak, cam atık çamuru, çok yaygın olarak zemin güçlendirme çalışmalarında tercih edilen, geleneksel bir iyileştirme malzemesi olan çimento (ÇMT) ile karşılaştırılmıştır. Bu karşılaştırmayı sağlayabilmek adına, hem aynı şartlarda zemine sadece farklı oranlarda çimento eklenerek hem de cam atı̆̆ ile çimento yine değişen oranlarda beraber kullanılarak bir dizi deney yapılmış ve elde edilen sonuçlar, Şekil 5, Şekil 6 ve Şekil 7' de sunulmuştur. Şekil 5' e bakıldığında, 25kPa gerilme kademesinde en büyük boşluk oranı 0.842 olarak saf kilde çıkmıştır. Saf kil için, zamana bağlı artan gerilme kademelerine bağlı olarak, boşluk oranı 0.790 değerine kadar düşmektedir. Ki zemine $\% 5, \% 10, \% 15, \% 20, \% 25$ ve $\% 30$ oranlarında CAÇ eklenmesi halinde, $25 \mathrm{kPa}$ gerilme kademesinden $400 \mathrm{kPa}$ gerilme kademesine kadar, boşluk oranları sirasiyla 0.834 ' ten 0.782 ' ye, 0.822 'den 0.771 ' e, $0.808^{\prime}$ den $0.758^{\prime}$ e e, 0.783 ' den 0.735 ' e, $0.768^{\prime}$ ' den 0.720 ' ye ve 0.765 'den 0.718 'e düşmüştür. Yani, CI içerisine, $\% 5^{\prime}$ den \%30' a varan oranlarda CAÇ eklenmesi durumunda, 25kPa' dan $400 \mathrm{kPa}$ ' a kadar olan gerilme kademelerinde, boşluk oranları 1.17 kata varan oranlarda azalmıştır. \%25 CAÇ oranına kadar boşluk oranlarındaki azalmalar yüksek oranlarda olurken, \%25' den sonraki değerlerde ciddi bir azalma kaydedilmemiş̧ir. Bu nedenle, bu tür killerde, zeminin zamana bağlı oturmalarındaki azalmalar için \%25 CAÇ oranının yeterli olduğu belirlenmiştir. Şekil 6' da, \%2, \%4, \%6 ve \%8 oranlarında ÇMT katkısı kullanılması durumlarında, farklı gerilme kademeleri için boşluk oranı değişimleri görülmektedir. $25 \mathrm{kPa}$ gerilme kademesinden $400 \mathrm{kPa}$ gerilme kademesine kadar, boşluk oranları sırasıyla 0.667 ' den 0.626 ' ya, 0.656 ' dan $0.615^{\prime}$ ' e, 0.627 ' den $0.588^{\prime}$ ' e ve $0.625^{\prime}$ den 0.586 ' ya düşmüştür. Böylece, ÇMT katkısı ile, CI' nin zamana bağlı boşluk oranlarında, yaklaşık olarak 1.44 kata varan azalmalar meydana gelmiş olduğu söylenebilir. Buradan, karışımlarda kullanılabilecek en iyi ÇMT oranı \%6 olarak belirlenmiştir. Bu orandan sonra, her gerilme kademesinde, boşluk oranlarında kayda değer azalmalar gözlemlenmemiştir. 


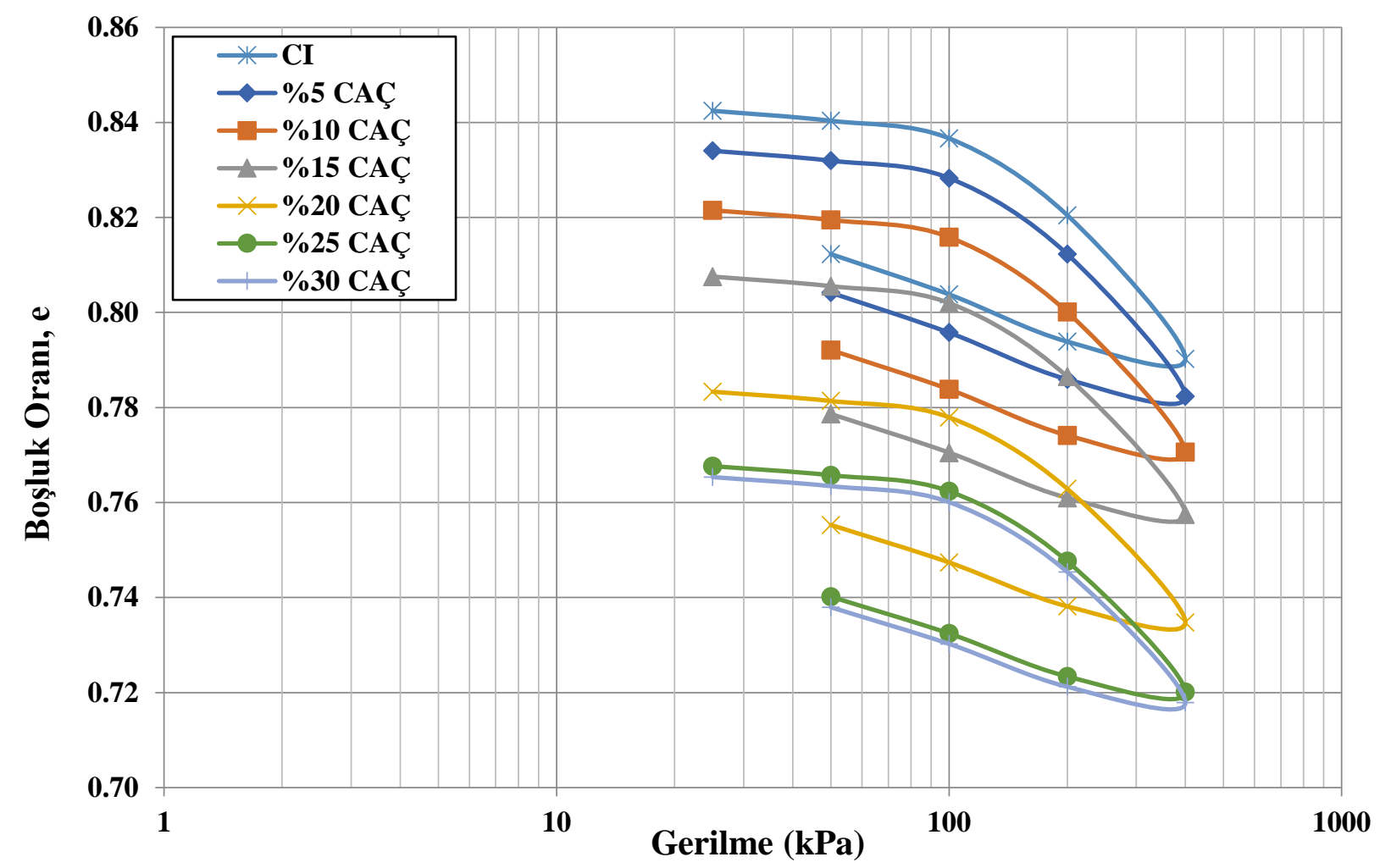

Şekil 5. CI ve farklı CAÇ oranları için boşluk oranı-gerilme grafikleri

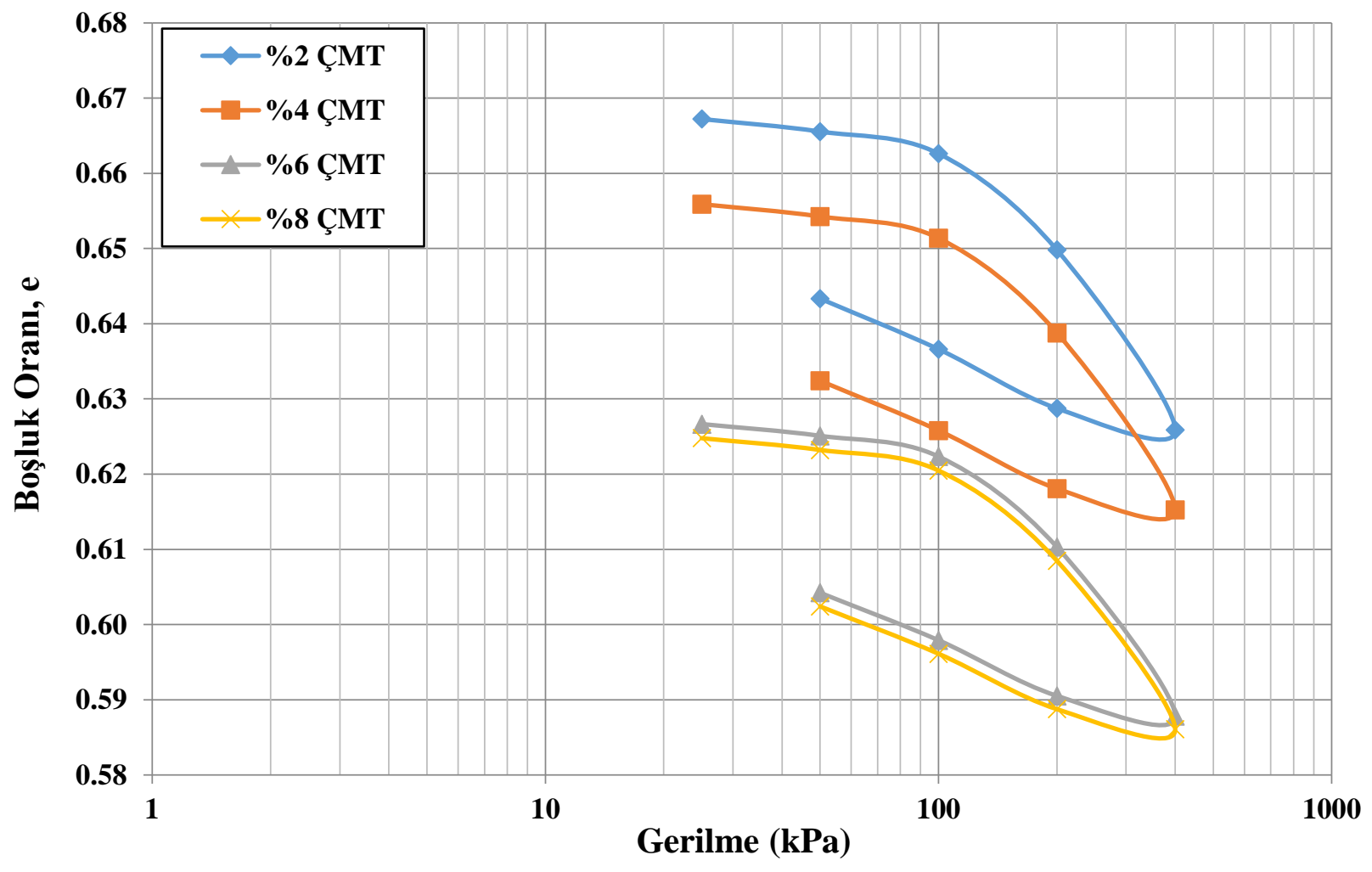

Şekil 6. Farklı ÇMT oranları için boşluk oranı-gerilme grafikleri 
Şekil 7' de ise, ideal CAÇ oranında ve farklı ÇMT oranlarında hazırlanan killi zeminin boşluk oranında meydana gelen değişimler gösterilmiştir. Sonuçlara göre, $25 \mathrm{kPa}$ gerilme kademesinden $400 \mathrm{kPa}$ gerilme kademesine kadar, boşluk oranları sırasıyla 0.649' dan 0.608 ' e, $0.624^{\prime}$ den $0.585^{\prime}$ e e, 0.622 ' den $0.584^{\prime}$ ' e ve 0.614 ' den 0.576 ' ya düşmüştür.

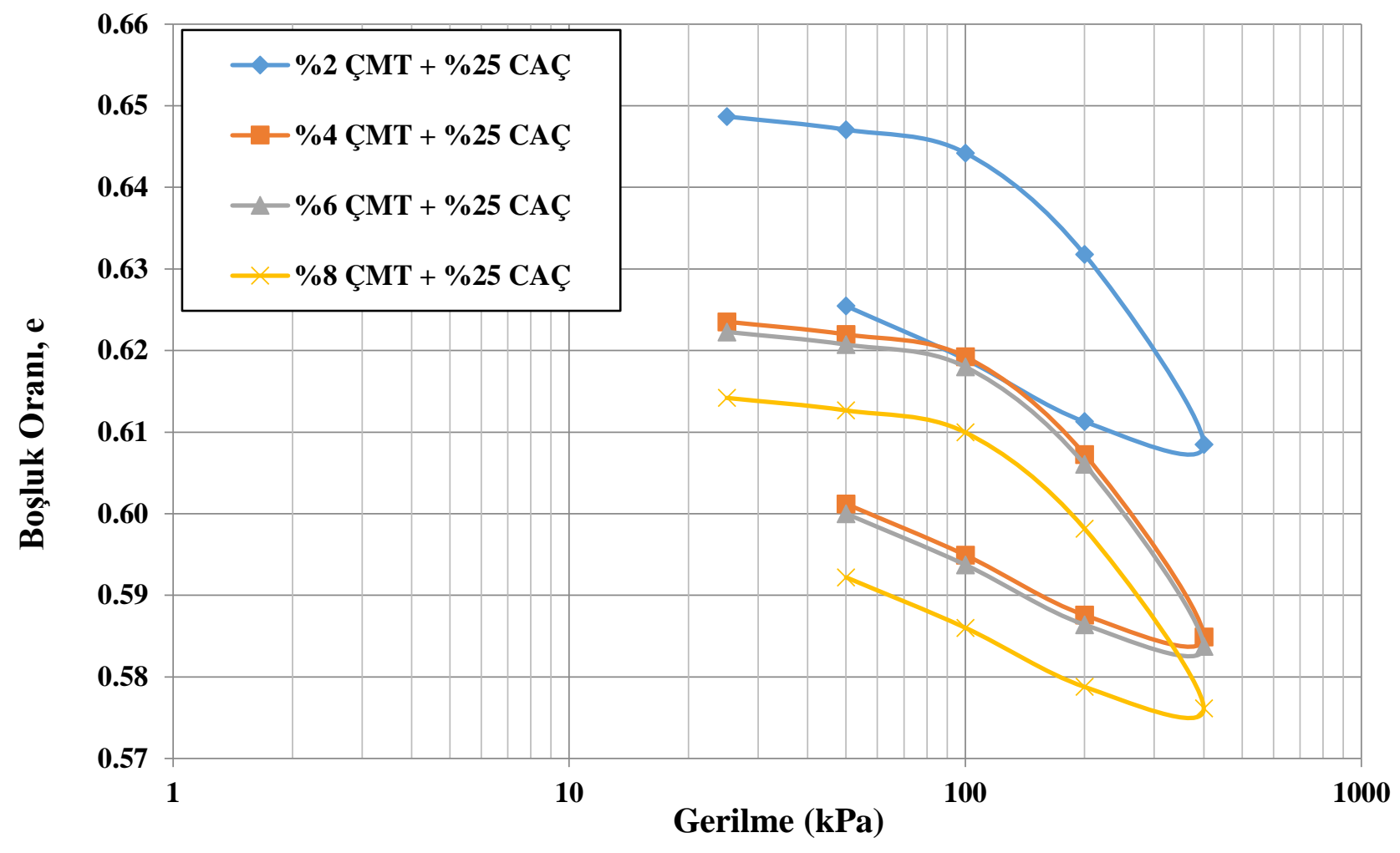

Şekil 7. \%25 CAÇ ve farklı ÇMT oranları için boşluk oranı-gerilme grafikleri

ÇMT ve CAÇ katkılarının ortak kullanımı, killi zeminin zamana bağlı boşluk oranlarında yaklaşık olarak 1.45 kata varan azalmalar meydana getirmiştir. CAÇ ve ÇMT karışımlarında, \%25 CAÇ ve \%6 ÇMT' nin en iyi oranlar olduğu belirlenmiştir. Zeminde zamana bağlı boşluk oranlarının azaltılmasında en iyi sonucu, CAÇ ile ÇMT' nin ortak kullanımı vermiştir. Artan gerilme kademelerine bağlı olarak, boşluk oranının azaltılması ile zemin daha sıkı hale gelmektedir. Böylece, zeminin taşıma gücü artarak zamana bağlı meydana getireceği oturma miktarı da düşecektir. Şekil 8, 9 ve 10' da sırasıyla, CAÇ, ÇMT ve CAÇ-ÇMT katkıları eklenmiş CI zeminler için şişme basınçları görülmektedir. Sadece CAÇ, sadece ÇMT ve CAÇ-ÇMT karışımları kullanılması durumlarında, şişme basınçlarında sırasıyla 1.60 kata, 1.68 kata ve 2.22 kata varan azalmalar meydana gelmiştir. Şişme basıncının azalmasında en iyi sonuç, CAÇ ve ÇMT' nin birlikte kullanılması ile elde edilmiştir. CI zeminlerin su ile teması halinde, üzerlerine gelen yapı yükleri nispeten hafif ise, zemin şişme davranışı sergileyecektir. Bu durumda da üst yapıda istenilmeyen hasarlar oluşacaktır. Bu katkıların kullanımı ile hem atıklar bertaraf edilmekte hem de şişme basınçları istenilen düzeylere getirilmektedir.

Öte yandan, sadece CI, \%25 CAÇ, \%6 ÇMT ve \%25 CAÇ-\%6 ÇMT kullanılması durumlarında, karışım numunelerinde ulaşılan şişme basıncı değerleri Şekil 11' de görülmektedir. Şekil 11' in incelenmesi sonucunda fark edilebilir ki, killi zemine \%25 oranında cam atığ1 eklenince zeminin şişme potansiyeli ciddi bir şekilde azalmaktadır. Burada bahsedilen şişme potansiyeli düşüşü, Şekil 11' den de gözlemlenebileceği gibi, ideal oranlarda çimento eklenmesi sonucu ortaya çıkan durumdan bile daha iyi sonuç vermektedir. İlave olarak, cam atığı ile çimentonun en iyi olduğu belirlenmiş olan oranlarda zemine eklenmesi sonucu ulaşılan şişme azalması, son derece dikkat çekici oranlarda gerçekleşmektedir. Bu sebepler bir arada irdelenecek olursa, sonuç olarak, çalışmada ele alınmış olan cam atı̆̆ının hem çimentoya yakın oranlarda iyileşmeler sağlaması ve çimento gibi popüler katkılarla beraber kullanımında çok iyi sonuçlar vermesi hem de pahalı kimyasal katkıların yerine geçebilme potansiyeli doğurarak oldukça daha ekonomik çözümlere ulaşım sağlaması gibi sebeplerle, zemin iyileştirme çalışmalarında değerlendirilebileceği fikri ortaya çıkmaktadır. 


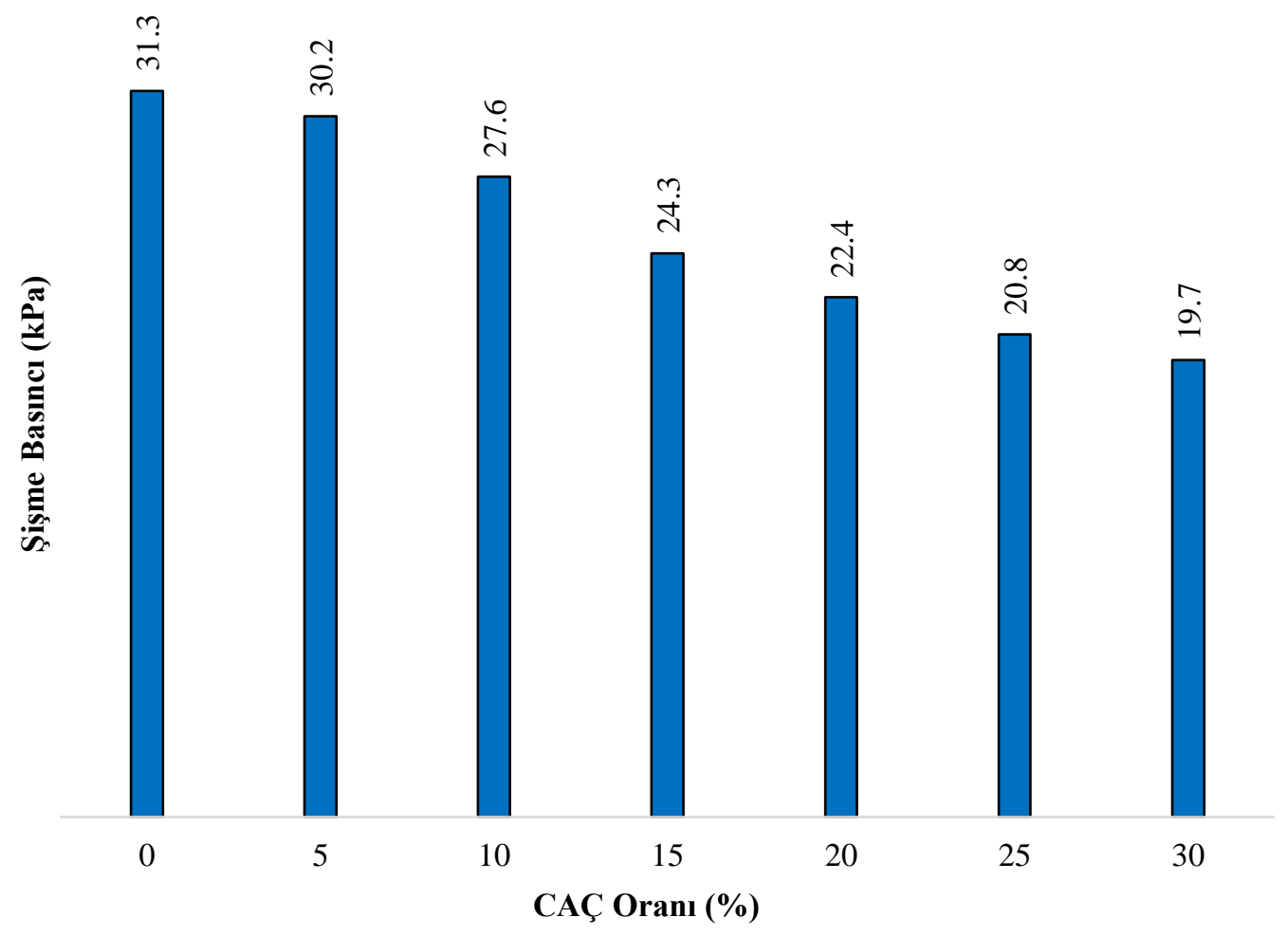

Şekil 8. CI ve farklı CAÇ oranları karışımları için şişme basınçları

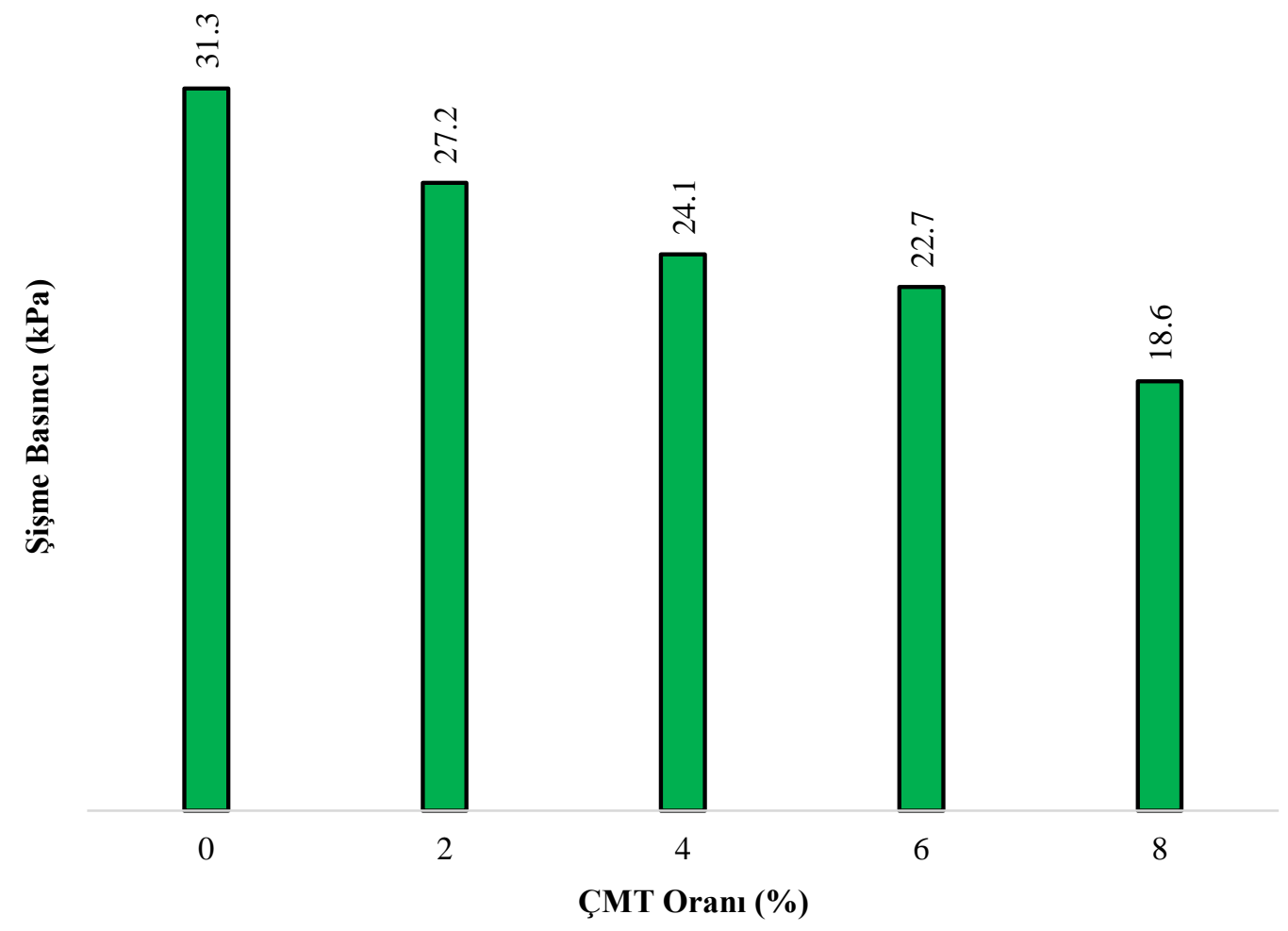

Şekil 9. CI ve farklı ÇMT oranları karışımları için şişme basınçları 


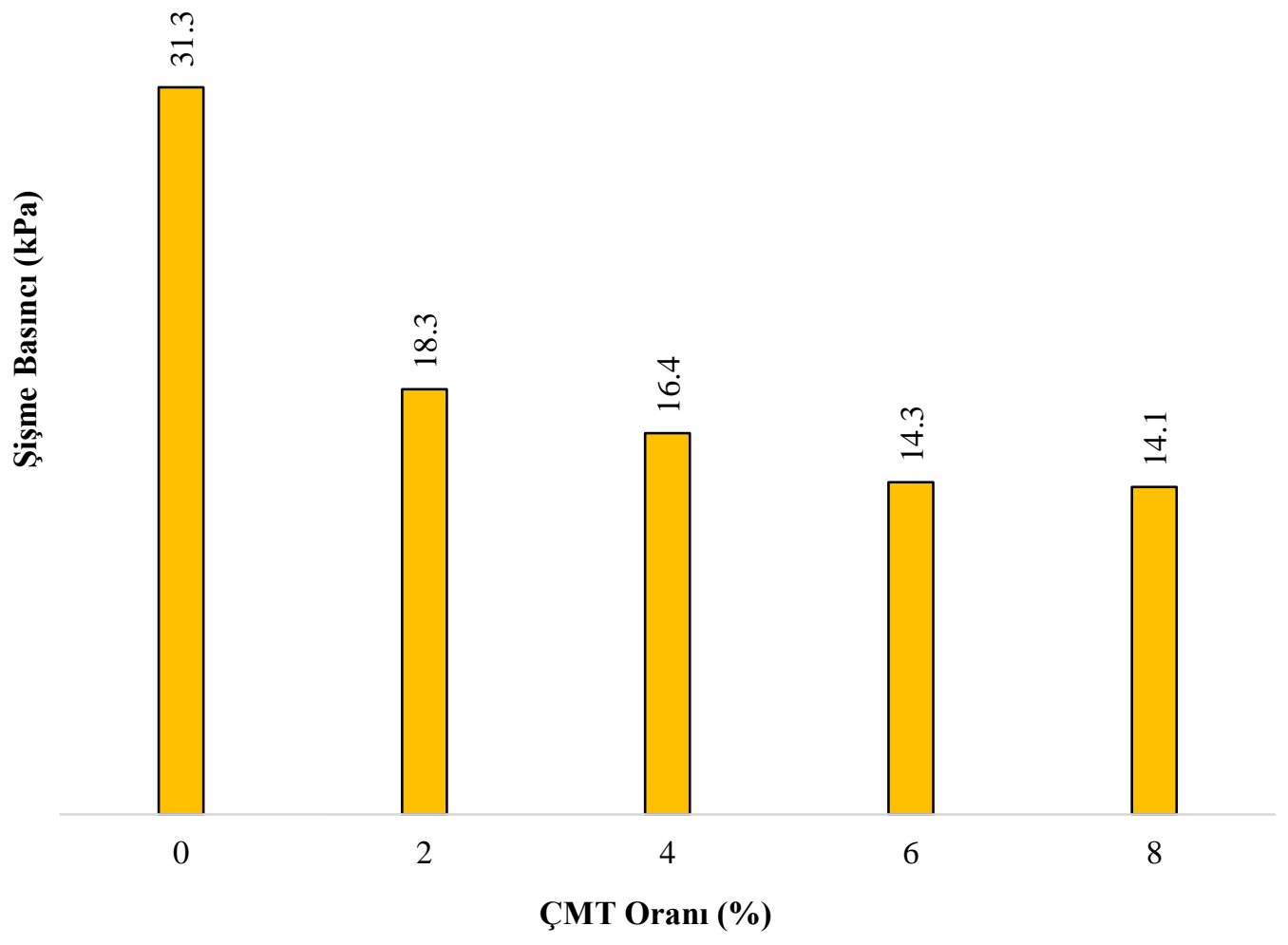

Şekil 10. CI, \%25 CAÇ ve farklı ÇMT oranları karışımları için şişme basınçları

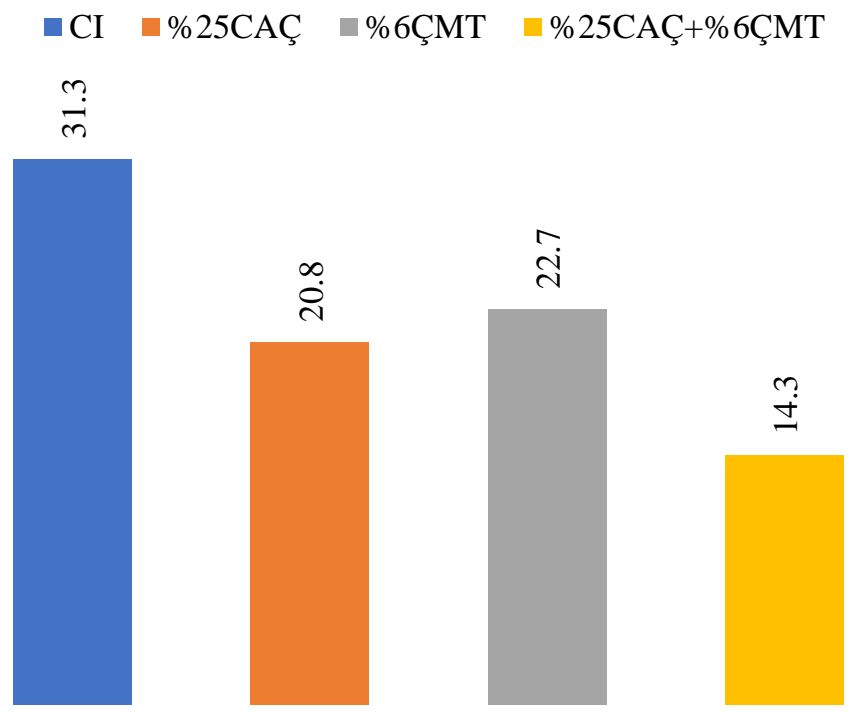

Şekil 11. CI, \%25 CAÇ, \%6 ÇMT ve \%25 CAÇ+\%6 ÇMT için şişme basınçları

\section{Sonuçlar}

Çalışmada, kil zemine (CI) belirli oranlarda cam atık çamuru (CAÇ) ve çimento (ÇMT) ilavesi ile hazırlanmış olan numunelerde oluşan mukavemet, konsolidasyon ve şişme parametrelerinin değişimlerinin araştııılmasına yönelik bir seri deney yapılmıştır. İlk olarak, kil zemine $\% 5, \% 10, \% 15, \% 20, \% 25$ ve $\% 30$ oranlarında CAÇ ilave edilerek serbest basınç deneyleri yapılmıştır. Bu deneyler sonrasında, $\% 5, \% 10, \% 15, \% 20, \% 25$ ve $\% 30$ oranlarında CAÇ, \%2, \%4, \%6 ve \%8 oranlarında ÇMT ve optimum orandaki CAÇ-\%2, \%4, \%6 ve $\% 8$ oranlarında ÇMT ilavesi ile oluşturulan numuneler üzerinde konsolidasyon ve şişme basıncı deneyleri yapılmıştır. Son olarak, optimum değerlerde belirlenen CAÇ, ÇMT ve CAÇ-ÇMT oranlarında şişme basıncı deney sonuçları karşılaştırılmıştır. Elde edilen sonuçlar aşağıda sunulmuştur. 
$>\mathrm{CI}$ içerisine, $\% 5, \% 10, \% 15, \% 20, \% 25$ ve $\% 30$ oranlarında CAÇ eklenmesi durumunda, serbest basınç mukavemetlerinde, her bir oran için sırasıyla 1.14, 1.36, 1.79, 2.16, 2.59 ve 2.60 oranlarında artışlar meydana gelmiştir. Ayrıca, ideal olarak tanımlanan $\% 25$ oranındaki CAÇ ile hazırlanan $\mathrm{CI}^{\prime}$ ye, $\% 2, \% 4, \% 6$ ve $\% 8$ oranlarında ÇMT eklenmesi durumunda, serbest basınç mukavemetlerinde her oran için sırasıyla 2.70, 2.87, 3.05 ve 3.22 oranlarında artış meydana geldiği tespit edilmiştir. Buradan, CI' nin serbest basınç mukavemetinin CAÇ ile arttırılabileceği belirlenmiştir. Ayrıca, ilave ÇMT etkisiyle de serbest basınç mukavemetlerinin daha da arttırılabileceği saptanmıştır.

> $25 \mathrm{kPa}$ ' dan $400 \mathrm{kPa}$ a kadar olan gerilme kademeleri için, zamana bağlı boşluk oranlarında, CI içerisine \%5-\%30 arası oranlarda CAÇ eklenmesi durumunda 1.17, \%2-\%8 arası oranlarda ÇMT eklenmesi ile 1.44 ve ÇMT ile CAÇ' nin birlikte kullanımıyla (\%25 CAÇ ve \%2-\%8 ÇMT) 1.45 kata varan azalmalar meydana geldiği tespit edilmiştir.

$>\mathrm{Bu}$ tür killerde, zeminin zamana bağlı oturmalarındaki azalmalar için, \%25 CAÇ ve \%6 ÇMT oranlarının kullanımının en ideal seçim olduğu belirlenmiş̧ir. Ayrıca, her iki katkının ideal oranlarda aynı anda kullanılması ile de en iyi sonuçların elde edileceği görülmüştür.

> Sadece CAÇ, sadece ÇMT ve CAÇ-ÇMT kullanılması durumlarında, şş̧me basınçlarında sırasıyla 1.60 kata, 1.68 kata ve 2.22 kata varan azalmalar meydana gelmiştir. Yine, şişme basıncındaki en iyi azalma, CAÇ ve ÇMT' nin birlikte kullanılması (\%25 CAÇ ve \%6 ÇMT) ile elde edilmiştir.

> Sonuç olarak, CI' lerin serbest basınç mukavemetleri, zamana bağlı oturmalar, boşluk oranı değişimleri ve şişme basınçları gibi parametrelerin iyileştirilmesinde, hem CAÇ' nin tek başına hem de CAÇ ve ÇMT' nin bir arada başarılı bir şekilde kullanılabileceği belirlenmiştir.

\section{Referanslar}

Abbaspour M., Aflaki E., Nejad F. M., (2019). Reuse of waste tire textile fibers as soil reinforcement. Journal of cleaner production, 207, 1059-1071.

Akbarimehr D., Aflaki E., Eslami A., (2019). Experimental investigation of the densification properties of clay soil mixes with tire waste. Civil engineering journal, 5(2), 363-372.

Arulrajah A., Mohammadjavad Y., Mahdi M. D, Suksun H., Myint W. B., Melvyn L., (2018). Evaluation of fly ash and slag-based geopolymers for the improvement of a soft marine clay by deep soil mixing. Soils and Foundations, 58(6), 1358-70. https://doi.org/10.1016/j.sandf.2018.07.005.

Ateş A., (2016). Mechanical properties of sandy soils reinforced with cement and randomly distributed glass fibers (GRC). Composites Part B: Engineering 96, 295-304. https://doi.org/10.1016/j.compositesb.2016.04.049.

Ayininuola G., Ayodeji I., (2016). Influence of Sludge Ash on Soil Shear Strength. Journal of Civil Engineering Research, 6(3), 72 77.

Ayodele A. L., Adebisi A. O., Kareem M. A., (2016). Use of Sludge Ash in Stabilising Two Tropical Laterite. Int. J. Sci. Eng. Res., 7.

Badrawi E. F., El-kady M. S., (2019). Stabilizing soft clay using geo-foam beads and cement bypass dust. Underground Space https://doi.org/101016/jundsp(2019)05003.

Bagriacik B., Mahmutluoglu B., (2020). A new experimental approach to the improvement of sandy soils with construction demolition waste and cement. Arab J Geosci, 13, 539. https://doi.org/10.1007/s12517-020-05493-6.

Basha E. A., Hashim R., Mahmud H. B., Muntohar A. S., (2005). Stabilization of residual soil with rice husk ash and cement. Constr. Build. Mater., 19(6), 448-453.

Bell F. G., (1996). Lime stabilization of clay minerals and soils. Engineering geology, 42(4), 223-37.

Bilondi M. P, Mohammad M. T., Vahid T., (2018). Experimental investigation of using a recycled glass powder-based geopolymer to improve the mechanical behavior of clay soils. Construction and Building Materials, 170, 302-13. https://doi.org/10.1016/j.conbuildmat.2018.03.049.

Biradar K. B., Arun K. U., Satyanarayana P. V. V., (2014). Influence of steel slag and fly ash on strength properties of clayey soil: A comparative study. International Journal of Engineering Trends and Technology (IJETT)- (14) (2). https://doi.org/10.14445/22315381/IJETT-V14P213.

Brooks R. M., (2019). Soil stabilization with fly ash and corn waste ash-improvements in engineering characteristics. Int. J. Appl. Eng. Res., 14(4), 1025-1030. 
Chang I., Jooyoung I., Moon-Kyung C., Gye-Chun C., (2018). Bovine casein as a new soil strengthening binder from diary wastes. Construction and Building Materials, 160, 1-9. https://doi.org/10.1016/j.conbuildmat.2017.11.009.

Cokca E., Yazici V., Ozaydin K., (2009). Stabilization of expansive clays using granulated blast furnace slag (GBFS) and GBFScement. Geotech. Geol. Eng., 27(4), 489.

Corrêa-Silva M., Nuno A., Nuno C., Tiago M., António T. G., Coelho J., (2018). Improvement of a clayey soil with alkali activated low-calcium fly ash for transport infrastructures applications. Road Materials and Pavement Design: 1-15. https://doi.org/10.1080/14680629.2018.1473286.

de Figueiredo Lopes Lucena L. C., ThoméJuca J. F., Soares J. B., Portela M. G., (2014). Potential uses of sewage sludge in highway construction. Journal of materials in civil engineering, 26(9), 04014051.

Esmaeilpour S. N., Abbasali T. G., Mohammadreza K. T., Asskar J. C., (2019). Improvement of the engineering behavior of sand-clay mixtures using kenaf fiber reinforcement. Transportation Geotechnics, 19, 1-8. https://doi.org/10.1016/j.trgeo.2019.01.004.

Fauzi A., Zuraidah D., Usama J. F., (2016). Soil engineering properties improvement by utilization of cut waste plastic and crushed waste glass as additive. International Journal of Engineering and Technology, 8(1), 15. https://doi.org/10.7763/IJET.2016.V8.851.

Gu K., Chen B., (2020). Loess stabilization using cement, waste phosphogypsum, fly ash and quicklime for self-compacting rammed earth construction. Construction and Building Materials, 231:117195.

Gupta C., Sharma R. K., (2014). Influence of marble dust, fly ash and beach sand on sub-grade characteristics of expansive soils. International Conference on Advances in Engineering and Technology, 13-18.

Güllü H., (2014). Factorial experimental approach for effective dosage rate of stabilizer: Application for fine-grained soil treated with bottom ash. Soils and Foundations, 54(3), 462-477.

Hasan H., Dang L., Khabbaz H., Fatahi B., Terzaghi S., (2016). Remediation of expansive soils using agricultural waste bagasse ash. Procedia Eng., 143, 1368-1375.

James J., Pandian P. K., (20169. Industrial wastes as auxiliary additives to cement/lime stabilization of soils. Adv. Civ. Eng., 1-17.

Jin L. M., MohdYunus N. Z, Hezmi M. A., Rashid A. S. A., Marto A., Kalatehjari R., Pakir F., Mashros N., Ganiyu A., (2018). Predicting the Effective Depth of Soil Stabilization for Marine Clay Treated by Biomass Silica. KSCE Journal of Civil Engineering, KSCE, 22(11), 4316-4326. https://doi.org/10.1007/s12205-018-1294-x.

Keerthi Y., Divya Kanthi P., Tejaswi N., Shyam Chamberlin K., Satyanarayana B., (2013). Stabilization of clayey soil using cement kiln waste. Int. J. Adv. Struct. Geotech. Eng., 2(2), 77-81.

Kianimehr M., Piltan T. S., Seyed M. B., Alireza M., Arul A., (2019). Utilization of recycled concrete aggregates for light-stabilization of clay soils. Construction and Building Materials, 227, 116792.

Kumar A., Gupta D., (2016). Behavior of cement-stabilized fiber-reinforced pond ash, rice husk ash-soil mixtures. Geotextiles and Geomembranes, 44(3), 466-74. https://doi.org/10.1016/j.jrmge.2016.05.010.

Kumar A., Sivapullaiah P. V., (2012). Improvement of strength of expansive soil with waste granulated blast furnace slag. In Geo Congress 2012: State of the Art and Practice in Geotechnical Engineering, 3920(8). https://doi.org/10.14445/22315381/IJETT$\underline{\mathrm{V} 11 \mathrm{P} 254 .}$

Lin D. F., Lin K. L., Luo H. L., (2007). A comparison between sludge ash and fly ash on the improvement in soft soil. J. Air Waste Manage, 57(1), 59-64.

Liu Y., Chang C. W., Namdar A., She Y., Lin C. H., Yuan X., Yang Q., (2019). Stabilization of expansive soil using cementing material from rice husk ash and calcium carbide residue. Construction and Building Materials, 221, 1-11.

Long G., Li L., Li W., Ma K., Dong W., Bai C., Zhou J. L., (2019). Enhanced mechanical properties and durability of coal gangue reinforced cement-soil mixture for foundation treatments. Journal of cleaner production, 231, 468-482. 
Mahmutluoglu B., Bagriacik B., (2021). Sustainable implementation of glass manufacturing waste and geogrids in the improvement of fine-grained soils. KSCE J Civ Eng 00(0), 1-13. https://doi.org/10.1007/s12205-021-1344-7.

MohdYunus N. Z., Wanatowski D., Abdul Hassan N., Marto A., (2016). Shear strength and compressibility behavior of lime treated organic clay. KSCE Journal of Civil Engineering, KSCE, 20(5), 1721-1727. https://doi.org/10.1007/s12205-018-1294-x.

Naseem A., Mumtaz W., De Backer H., (2019). Stabilization of expansive soil using tire rubber powder and cement kiln dust. Soil Mechanics and Foundation Engineering, 56(1), 54-58.

Pastor J. L., Tomás R., Cano M., Riquelme A Gutiérrez E., (2019). Evaluation of the improvement effect of limestone powder waste in the stabilization of swelling clayey soil. Sustainability, 11(3), 679.

Pourakbar S., Afshin A., Bujang B. K. H., Mohammad H. F., (2015). Stabilization of clayey soil using ultra fine palm oil fuel ash (POFA) and cement. Transportation Geotechnics, 3, 24-35. https://doi.org/10.1016/j.trgeo.2015.01.002.

Ramakrishna A. N, Pradeepkumar A. V., (2006). Stabilization of black cotton soil using rice husk ash and cement. In National Conference on Civil Engineering Meeting the Challenges of Tomorrow, GND Engineering College, Ludhiana, 215-220.

Shah S. A. R., Mahmood Z., Nisar A., Aamir M., Farid A., Waseem M., (2020). Compaction performance analysis of alum sludge waste modified soil. Construction and Building Materials, 230, 116953.

Sharma R. S., Phanikumar B. R., Rao B. V., (2008). Engineering behavior of a remolded expansive clay blended with lime, calcium chloride and rice- husk ash. Jnl. of Mat. in Civil Eng, 20(8), 509-515.

Taki K., Choudhary S., Gupta S., Kumar M., (2020). Enhancement of geotechnical properties of municipal sewage sludge for sustainable utilization as engineering construction material. Journal of Cleaner Production, 251, 119-723.

Tremblay H., Josée D., Jacques L., Serge L., (2002). Influence of the nature of organic compounds on fine soil stabilization with cement. Canadian Geotechnical Journal, 39(3), 535-46.

TS 1500, (2000): İnşaat Mühendisliğinde Zeminlerin Sınıflandırılması, Türk Standartları Enstitüsü. Ankara.

TS 1900-1, (2006): İnşaat Mühendisliğinde Zemin Laboratuvar Deneyleri - Bölüm 1: Fiziksel Özelliklerin Tayini. Türk Standartları Enstitüsü. Ankara.

TS 1900-2, (2006): İnşaat Mühendisliğinde Zemin Laboratuvar Deneyleri - Bölüm 2: Mekanik Özelliklerin Tayini. Türk Standartları Enstitüsü. Ankara.

Ural N., Karakurt C., Cömert A. T., (2014). Influence of marble wastes on soil improvement and concrete production. J. Mater Cycles Waste Manag., 16, 500-508. https://doi.org/10.1007/s10163-013-0200-3.

Yadav J. S., Hussain S., Tiwari S. K., Garg A., (2019). Assessment of the load-deformation behavior of rubber fibre-reinforced cemented clayey soil. Transportation Infrastructure Geotechnology, 6(2), 105-136.

Yokohama S., Sato A., (2019). Cyclic mechanical properties of sandy soils by mixing recycled asphalt pavement material. International Journal, 16(58), 41-47.

Zainuddin N., Yunus N. Z. M., Al-Bared M. A. M., Marto A., Harahap I. S. H., Rashid A. S. A., (2019). Measuring the engineering properties of marine clay treated with disposed granite waste. Measurement, 131, 50-60.

Zhan T. L., Zhan X., Lin W., Luo X., Chen Y., (2014). Field and laboratory investigation on geotechnical properties of sewage sludge disposed in a pit at Changan landfill, Chengdu, China. Engineering geology, 170, 24-32. 